\title{
ANA DİL VE ANNE DİLİ KAVRAMLARI
}

\section{THE CONCEPTS OF "HOUSE" LANGUAGE AND OFFICIAL LANGUAGE}

\section{КОНЦЕПТЫ «РОДНОЙ ЯЗЫК» И «МАТЕРИНСКИЙ ЯЗЫК»}

\section{Ergun ÇELIK*}

\section{ÖZ}

Dil, her milletin doğal bir anlaşma aracı, kendine özgü sosyal yapısının harcıdır. Her milletin ortak bir dili, ortak bir kültürü ve ortak bir inancı vardır. Milletin ortak dili ana dildir.

Ana dil, toplumun her kesiminde sarsılmaz bir birlik yaratır. Aralarında anlaşma dizgesini oluşturur. Ulusları oluşturan bütün bireyler bu birlikten paylarına düşeni alırlar. $\mathrm{Bu}$ bakımdan ana dil milleti oluşturan ana unsurdur.

Ana dil, ulusun sarsılmaz harcı, birleştiricisidir. Bu parçalar ulusta birleşir. Çayların, derelerin nehirlerde birleştiği gibi

Anne dili: Başlangıçtan itibaren Anne - baba ve yakın aile bireylerinden duyulup taklit edilerek öğrenilen dildir. İnsanoğlu konuşma yeteneği ile doğar. Söylenenleri duyup taklit eder.

Tümceleri, sözcükleri hatta sesleri “fonemleri” duyup tekrarlayarak öğrendiği unutup, anımsamalarla ve zorunlu ihtiyaçlarını karşılamak üzere kullanmak istediği araçtır.

Anne dili doğuştan bilinemez. Uzun bir zamanda, duyup taklit etme uğraşından sonra öğrenilir. Bu duyup, taklit ederek öğrendiği dile de doğal olarak "anne dili” denir. Anne dili 'söz bir bütündür' ilkesinden geçer.

Milletlerin kültür birikimini aktaran, bireyleri arasında anlaşmayı sağlayan en doğal araç kuşkusuz ana dildir. Dil; dinleme, konuşma, okuma ve yazma etkinliklerinin kaynağıdır. Hatta bütünüdür.

Okul dili Resmî dildir. Bu resmî dil okunduğu gibi yazılan, yazıldı̆̆ı gibi okunan dildir. En güzel örneği İstanbul Türkçesidir. Misak-1 milli sınırları dâhilinde resmî dil olarak kullanılan Türk dili millî ve devlet dilidir. Devletle ilgili olandır. Devletin koşulsuz birleştiği dildir.

Millet: Çoğunlukla aynı topraklar üzerinde yaşayan, aralarında dil, tarih, duygu, ülkü, gelenek ve görenek birliği olan insan topluluğu.

Dünyanın en çağdaş, en modern, en hoşgörülü millet tanımı, Gazi Mustafa Kemal Atatürk'e ait olup, Türkiye Cumhuriyeti’nin kurucu ideolojisinde yerini almıştır.

“Türkiye Cumhuriyeti’ni kuran Türkiye halkına Türk Milleti denir.” diye tanımlıyor.

1. DOI : $10.17498 /$ kdeniz.466

* . Yrd. Doç. Dr. Siirt Üniversitesi Eğitim Fakültesi İlköğretim Bölümü "Sınıf Öğretmenliği” Ana Bilim Dalı Öğretim Üyesi / Sİ̈RT (e-mail cergun98321@gmail.com) 
Ulusallık, resmî dilden temelini alır. Milleti oluşturan bütün unsurların harcı, birleştiricisi, temeli "ana dil" ile ifade bulur. Milletlerin ana dili resmî dildir. Resmî dil Etnik farklılıkların ortak adıdır.

Anne dili; aile ve çevreyi, ana dili ise bütün bu aileleri ve çevreleri içine alan vatan genelini temsil eder. Temelinde Ulus Devlet harcı bulunan milletlerin; hiçbir etnik, mezhepsel, dinsel, sosyal, kültürel nedenlerle ayrıştırılması mümkün değildir. Bunun anlamı; Misak-1 milli sınırları dâhilinde Türklük, Araplık, Kürtlük, Çerkezlik, Arnavutluk, Boşnaklık, Lazlık, Türkmenlik, Zazalık, Tatarlık hatta Ermenilik, Rumluk ve Süryanilik, Yezidîlik de vardır. Bütün bu etnik grupların anlaşabildiği ortak dil ana dildir. Bu da Türkçedir.

Anahtar Kelimeler: Ana Dil, Anne Dili, Yazı Dili, Konuşma Dili ve Türkçe

\section{ABSTRACT}

Language is a natural medium that bolsters social structure. Each nation has common language and a common culture. Language symbolizes unity among different people.

Language creates an unshakable unity of all sections of society, constitutes an agreement between all the individuals that make up the nation. Language is the main element to maintain communication between people.

House language, on the other hand, is heard and learned by imitating immediate family members. Human beings are born with the ability to talk, mimicking what is being said.

Phrases, words or even sound "phonemes" are heard repeatedly at home or in the neighborhood to meet the essential needs of everyday life. House language as different from nation's main language is only spoken among family members.

Nations transmit the cultural heritage through official, main language. Official language mostly finds a place in books in written form. Likewise, language taught in schools is the official language. Turkish language in the form of 'Istanbul Turkish' is the most beautiful example of Turkish. Turkish language is the official language used within the Misak-1 Milli borders. It unconditionally bridges all the elements of the state.

Nations: All people who live in the same land, binded by language, history, emotions, ideals, traditions and customs. (TDK: Turkish Dictionary, p, 1683).

The world's most modern, the most eloquent definition of nation belongs to Mustafa Kemal Atatürk, the great founder of the Republic of Turkey.

"People who contributed to the foundation of the Republic of Turkey" are considered Turkish regardless of their ethnic origins. The main language is the official language of the nation. The official language is the common name for ethnic differences. Mother tongue, or house language have a place in family and surroundings, the official language represents the overall homeland and encompasses all of these families and their life as a whole.

Although different ethnic groups live within Misak-1 Milli borders, such as Arabs, Kurds, Circassians, Albanians, Bosnians, Lazs, Turkmens, Zazas, Armenians and Greeks etc., Turkish as official language is the shared language of all these groups, through which they can speak and communicate.

Key Words: Official Language, House Language, Written Language, Spoken Language, Turkish. 


\section{АННОТАЦИЯ.}

Язык для каждого народа является средством понимания, уникальной социальной структурой. У каждого народа есть общий язык, общая культура и общая вера. Общим для народа является родной язык.

Родной язык в каждом сегменте общества создает единство, выстраивает понимание между членами общества. Создавшие государство люди вместе составляют судьбу. В этом аспекте родной язык является важнейшим элементом создания нации. Родной язык есть могучее средство государства, его объединяющая сила. Эти части соединяются в стране. Словно ручьи, потоки, соединяющиеся в реки.

Материнский язык: с самого рождения слышимая речь от матери, отца и близких родственников усваивается посредством имитации. Ребенок рождается со способностью к общению. Слушая речь, он имитирует. Фразы, слова, даже звуки «фонемы» он усваивает, повторяя. Затем, забыв об этом, он, вспоминая усвоенное, использует язык для удовлетворения необходимых потребностей.

Материнский язык невозможно знать с рождения. В течение большого времени слыша, имитируя, можно ему научиться. Изученный посредством слушания, повторения язык называется «материнским языком». Материнский язык определяется через принцип «единство языка».

Язык, передающий культуру нации, служащий для понимания различных слоев населения естественно называется родным. Язык, слушание, общение, чтение и письмо относятся к составляющим способности.

Школьный язык является официальным. Официальный язык - это язык, в котором читается как пишется и пишется, как читается. Лучшим примером является стамбульский диалект. Язык, используемый в пределах Турции в качестве официального является национальным и государственным. Это язык единства и целостности государства. Нация - это общность людей, проживающая на данной территории, объединенная одним языком, историей, чувствами, традициями, взглядами и границами (ТДК: Турецкий словарь, с.1683).

Ключевые слова: родной язык, материнский язык, письменный язык, язык общения, турецкий язык.

\section{GíRiş}

Dilin tanımları ve dizgelerini belli kalıplara, kurallara göre eğitimini, öğretimini ve Türkçenin zenginliğini ele alanlar, çeşitli yönlerden yaklaşmışlardır.

$\mathrm{Bu}$ yaklaşımlar; Dilin düşüncenin aynası olduğunu, insanlar duygu ve isteklerini bu dizgeden yararlanarak ifade ettiklerini ortaya koyarlar. Anlaşmayı; konuşup, yazışmayı ve bu haberleşmenin yalnızca insana ait olduğunu iletmektedirler. Belirtildiği gibi milleti birleştiren, koruyan, sonsuza kadar devam ettiren ve ayakta tutan bu canlı araç dildir. Bu dizgenin fonetik ve morfolojik yapısına, belli uyumlarına, özelliklerine ve benzeşmelerine tam anlamıla sahip çıkılmalıdır. Geniş sahası olan ağız denen şubesinde Anadolu'nun en uzak köşesine kadar önemini ve toplumsal işleve sahip olduğunu ortaya koymak gerekir.

Dil doğal bir anlaşma aracı, bireylerin duygularını, düşüncelerini, fikirlerini, hükümlerini birbirlerine nakletmek, meramlarını birbirlerine anlatmak amacını ortaya 
koyar. Ulusun bütün bireyleri gizli antlaşmalar yapmış durumdadırlar. Dil her Ulusun kendine özgü sosyal yapısının harcıdır.

Ulusallık resmî dilden temelini alır. Milleti oluşturan bütün unsurların harcı, birleştiricisi, temeli "ana dil" ile ifade bulur. Milletlerin ana dili resmî dildir. Resmî dil Etnik farklılıkların ortak adıdır. Ana dili budur.

Bireylerin içinde yaşadığ 1 ulusun, ulusal sesini, ulusal çehresini en iyi yansıtan; birlik yaratan, canlı anlaşma aracı olarak kullandığı dildir. Halk arasında kullanılıp anlamı bilinen fakat Türkçe olmayan sözcükleri alırken bile onlara millî bir ahenk kazandıran, millet harcı olan anlaşma aracı yine ana dildir. Bu ana dil, Anadolu coğrafyasına hâkim olan en güzel, en halis Türkçedir.

"Dil, bir milletin kültürel değerlerinin başında gelir. Bundan dolayı ona büyük ehemmiyet vermek gerekir.

Aynı dili konuşan insanlar 'millet' denilen sosyal varlığın temelini teşkil ederler. Dil duygu ve düşünceyi insana aktaran bir vasıta olduğu için, insan topluluklarını bir yığın veya kitle olmaktan kurtararak, aralarında 'duygu ve düşünce birliği' olan bir cemiyet, yani 'millet' haline getirir. Dilini bilmediğimiz bir ülkede, milyonlarca insan kaynaşsa da kendimizi yalnız hissederiz.

Fert konuştuğu dili hazır bulur. Dil ferde cemiyetin bağışladığı en büyük miras ve donatımdır. Biz dili, kelime kelime değil cümle cümle öğreniriz." (kaplan: 1983 s,44)

\section{ANA DİL VE TÜRKÇE}

“Milletin çok açık niteliklerinden biri DİL'dir. Türk Milletindenim diyen insan, her şeyden önce ve mutlaka Türkçe konuşmalıdır. Türkçe konuşmayan bir insan Türk düşüncesine bağlı olduğunu iddia ederse, buna inanmak doğru olmaz. GAZİ MUSTAFA KEMAL ATATÜRK" (Önder:1998, s.8)

Türk Dilinin yasalarından biri olan, "kalınlık - incelik uyumu” başlangıçtan bugüne kadar Türkçenin her devrinde çok kuvvetli olarak hâkim bulunmuş olan ve olmakta devam eden bir kaidedir. Türkçenin en büyük fonetik hususiyetini bu kaide teşkil eder. Türkçeye giren ve böyle bir uyum taşımayan yabancı kelimeler bile ağızlarda geniş ölçüde kalınlık incelik uyumuna tabi tutulurlar. Türkçenin bu uyum dışında kalan istisnaları çok azdır ve başka sebeplerle sonradan ortaya çıkmışlardır. Meselâ anne, inanmak, hangi, hani, dahi gibi Türkçe kelimelerde kalınlık - incelik uyumuna aykırı durumlarla karşılaşırız. Fakat bunların hepsi Türkçede sonradan çıkmış istisnalardır. Bunlardan anne çocuk dilinde ana kelimesinin bozulmuş şeklidir.”(Ergin, 1958: 62).

Anne dili: Başangıçtan itibaren Anne - baba ve yakın aile bireylerinden duyulup taklit edilerek öğrenilen dildir. İnsanoğlu konuşma yeteneği ile doğar. Önce etrafındaki sesleri duyar. Anne, baba ve yakın aile bireylerinden söylenenleri duyup taklit eder.

Dil, çocuğun unuttuğu, bütünü ifade eden tümceleri, sözcükleri hatta sesleri "fonemleri" duyup tekrarlayarak öğrendiği ve zorunlu ihtiyaçlarını karşılamak üzere kullanmak istediği araçtır. Anne dili doğuştan bilinemez. Uzun bir zamanda, duyup taklit etme uğraşından sonra öğrenilir.

Dilin malzemesi olan sesleri şekillendirerek, duyup, taklit ederek öğrendiği dile de doğal olarak "anne dili” denir. Bu uğraş başlangıçtan itibaren çocuğun zarurî ihtiyaçlarını karşılamak için kullanılır.

Anne dili 'söz bir bütündür' ilkesinden geçer. 
Çocuk taklit ettiği seslerden örülü tümceleri ve sözcükleri bütün olarak, ayrıştırmadan öğrenir. Örneğin 'Ali top oyna' tümcesinin sözcüklerini; ayrı ayrı değil, bir bütün olarak öğrenir. Bu bütünlük Ali’nin top oynama eyleminin adıdır. Önce tümceyi, sonra tümceyi oluşturan sözcükleri başka söyleyişlerde duyup, gördüğü zaman sözcüğü bütün olarak alır. $\mathrm{Bu}$ ayrıştırma foneme kadar devam eder.

Bireyin duyup taklit ederek öğrendiği bu 'anne dili'ni kullanmak için “dil” denen et parçasına ihtiyaç vardır. Ağzımızın içindeki bu et parçasının hareketleri kavislenip ileri geri gidip gelmesi sesleri canlandırır. Bundan dolayı bu dizgeye "dil” denmektedir. Bu et parçası hareket etmezse sesleri canlandıramayız. Hiçbir sesi çıkaramayız. Hiçbir çağrışma eylemini gerçekleştiremeyiz. Türk Dili, Fransız Dili gibi

Anne dili: "Başlangıçta anneden ve yakın aile çevresinden, daha sonra da ilişskili bulunulan çevrelerden öğrenilen, insanın bilinçaltına inen ve bireylerin toplumla en güçlü bağlarını oluşturan dildir." (Aksan, 1979: 81- 82).

Dilin ya da dillerin eskiliği bakımından veya doğuşu konusunda, kesin bilgiler yoktur. Yalnız en eski dil olarak 'Ahd-1 Atik' dili (Tevrat Dili) olduğu kabul edilmektedir. Bu dilin hangi coğrafyada kullanıldığı da bilinmemektedir.

“Ziya Gökalp, dili kültürün temel unsuru sayar. O, bu görüşünde haklıdır. Zira dil duygu ve düşüncenin âdeta kabıdır. ..... Dil kültürün temeli olduğuna göre, bir milletin dil ile ifade ettiği sözlü, yazılı her şey kültür kavramına girer.(Kaplan: 1982, s. 186)

\section{DİL}

“Dil deyince, konuşulan ve yazılan kelime ve cümleleri anlamak lazımdır. Halk günlük hayatında kelimeleri menşelerine göre ayırmaz. Onu ilgilendiren kelimelerin manası, işe yaramasıdır. ... Dil ile tarih ve kültür arasındaki münasebeti bilen bir kimse, dili tek başına almaz. Zira dilde her kelimenin yazılış, ses, şekil ve manasını tayin eden tarih ve kültürdür. Yunus Emre'nin şiirlerinin dilini, yazıldığı devir ve çevreden ayrı ele alamazsınız. Zira o ağacın kökleri gelenek ile beraber, yetiştiği topraklara sımsıkı bağlıdır.’'( Kaplan: 1983, s187)

Halk arasında anlaşma aracı olan sözcüğün; yabancı asıllı olup olmadığı değil, anlamı biliniyor ve kullanılıyorsa, o sözcük Türkçeleşmiş demektir. Demek ki halk; sosyal, kültürel ve ekonomik anlamda yapılan alış verişlerden dolayı alınan sözcükleri kendisine mal edip, Türkçe asıllı olmadığı halde, bu sözcükleri Türkçeleştirir. Onu günlük yaşamında kullanır. Çünkü halk sözcügünün bir anlamı da "yaratmak" demektir. (TDK Türkçe Sözlük: 2011, s, 1033)

"Türk halkının bildiği ve tanıdığı her kelime millîdir. Bir kelimenin millî olması için, Türkçe kökten gelmesi kâfi değildir.” (Kaplan:1990, s123)

“Türk halkının bildiği ve kullandığı her kelime Türkçedir, halk için munis olan ve sun’i olmayan her kelime millîdir. Bir milletin dili kendisinin cansız köklerinden değil, canlı tasarruflarından kurulan, canlı bir uzviyettir.” (Kaplan:1990, s139)

"Bir dilin iki cephesi vardır. Biri insanların karşı karşıya sesli olarak görüşürken, yani konuştukları zaman kullandıkları konuşma dili; diğeri yazıda kullanılan, yani insanların söylemek istediklerini yazı ile anlatırken kullandıkları yazı dilidir.” (Ergin: 1958, s, 6)

Yazı Dili: Sesin, harfe dönüşmesinden meydana gelen anlatım dilidir. A sesinin A harfine dönüşmesi için uzun bir süre gerekmiş, bu uzun sürenin üç bin yıl olduğu söylenir. Yazı dili, yazacak olan kişinin sözcük dağarcığına dayanır. Sözcük dağarcığı geniş olan yazıcı, etkileyici biçimde yazar. Yazılı anlatımla ifade bulan anlatım yolu; bir birlik, bir 
denge ve bir canlılık ifadesi taşır. Birlik, denge ve canlılık, önce tümcede, paragrafta ve yazılı anlatımın tümünde hüküm sürer. $\mathrm{Bu}$ yazılı anlatım, anlatılanı gözlerimizin önünde canlandırır. Betimler, somut hale getirir. $\mathrm{Bu}$ anlatım yoluna resmedercesine anlatım da denebilir. Yazılı ve sözlü olmak üzere iki anlatım yolu vardır. Dilin üç şubesi vardır. Ağız, Şive ve Lehçe

"Yazı dili eserlerde, kitaplarda, tek kelime ile yazıda kullanılan dildir. Yazı dili bir medeniyet dilidir. Tarih boyunca ancak medeniyeti, kültürü, edebiyatı olan kavimlerin yazı dilleri olmuştur. Yazı dili bir kavmin kültür dili, edebiyat dili olduğu için ona edebi dil de denir." (Ergin: 1958, s, 7)

Yazı dili: Bireyin düşündüğünü, duyduğunu, gördüğünü ve yaşadığını yazarak anlatmasıdır. Özellikle güzel yazmak isteyen birey için kültür dili bir zorunluluktur. Bu beceri dilin yapısını, uyumlarını, benzeşmelerini ve yazım kurallarının da iyi öğrenilmesiyle kazanılır.

Konuşma Dili: Evde, sokakta, her günkü hayatta kullanılan tabiî dildir.”(Ergin: 1958, s, 6) "Yazı dili, dayandığı konuşma diline bile yüzde yüz uymaz. Onun içine, bağlı olduğu konuşma dilinin dışındaki diğer konuşma dillerinden de bazı unsurlar girebilir. Bu suretle yazı dili yalnız bir konuşma ile kalmayıp, bir dil sahasının çeşitli kaynakları ile beslenir. Hatta bazen yabancı dillerin çeşitli unsurlarının istilasına uğrayarak büsbütün sun'i bir dil haline bile gelebilir. Sonra yazı dili konuşma diline göre daha muhafazakârdır. Bağlı olduğu konuşma dilindeki değişme ve gelişmeler hemen yazı diline aksetmez. Gerçekten bugün yazı dilimizle onun bağlı olduğu İstanbul Türkçesi arasındaki ayrılık yok denecek bir derecededir. $\mathrm{Bu}$ yüzden İstanbul Türkçesi yazı dili vasıtasıyla yurdun diğer konuşma bölgelerine de bir konuşma dili olarak yerleşmekte, bilhassa okumuşlar çevresini içine almak üzere, bütün Türkiye çapında bir konuşma dili haline gelmektedir.” (Ergin: 1958, s, 7-8)

Tanımı: "Dil, insanlar arasında anlaşmayı sağlayan tabiî bir vasıta, kendisine mahsus kanunları olan ve ancak bu kanunlar çerçevesinde gelişen canlı bir varlık, temeli bilinmeyen zamanlarda atılmış bir gizli antlaşmalar sistemi, seslerden örülmüş içtimaî bir müessesedir." (Ergin, 1977: 1).

\section{Tabiî bir vasita}

"Dil, insanlar arasında anlaşmayı sağlayan tabiî bir vasıtadır. İnsanlar duygularını, düşüncelerini, fikirlerini, hükümlerini birbirlerine nakletmek, meramlarını birbirlerine anlatmak için dil denilen vasıtaya başvururlar. Fakat dil, insanların kullandığı her hangi bir vasıtaya benzemez. Onun vasıtalığı sadece anlaşmayı temin etmesi bakımındandır. (Ergin, 1977: 1).

\section{Gizli antlaşmalar sistemi:}

"Dil bir gizli antlaşmalar sistemidir. Canlı ve cansız varlıkları, mefhumları, hareketleri karşılayan kelimeler üzerinde, kelimelerin birbirleri ile münasebetleri ve fikirleri anlatmak için yapılan kelime sırası üzerinde bir cemiyetin, bir kavmin, bir milletin bütün fertleri gizli anlaşmalar, gizli sözleşmeler yapmış durumdadırlar. Bu suretle bir cemiyetin bütün fertleri bir varlığı hep aynı kelime ile karşılarlar. Mesela Türkler bildiğimiz sert cisme taş, suya su, 1şığa 1şık demek için adeta sözleşmişlerdir. Bu sözleşmeyi, bu gizli anlaşmayı her cemiyet, her kavim ayrı bir şekilde yapmış, böylece her kavmin ayrı bir dili olmuştur. Aynı bir varlığa Türkler taş, Farslar seng, Araplar hacer demişlerdir. Çünkü her kavmin ayrı bir gizli antlaşmalar sistemi vardır." (Ergin, 1977: 2 -3). 


\section{İçtimâ̂ ve milli müessese:}

Dil, içtimaî bir müessesedir. Fertlerin üstünde, bütün bir cemiyetin malı olan ve bütün bir cemiyeti içine alan kuvvetli bir müessesedir. Cemiyetlerin en büyük dayanağı dildir. Bir cemiyeti ayakta tutan, bir cemiyetin varlığını sağlayan, devam ettiren bir cemiyette sarsılmaz bir birlik yaratan müessese olarak dilin oynadığı rol çok büyüktür. Bu bakımdan dil, milleti teşkil eden unsurların başında gelir. Bir milleti, bir kavmi bazen tek başına ayakta tutar, milli benliği muhafaza ederek, onu yok olmaktan, eriyip başkalaşmaktan kurtarır. Demek ki dil, bir milletin en büyük milli müessesesidir. Bu içtimaî ve milli müessesenin malzemesi ise seslerdir, yapısı seslerden örülmüştür.” (Ergin, 1977: 3).

“Dil, en kısa tanımıyla, sözlü iletişim aracıdır”. (Koç, 1990: 13).

"Dar anlamıyla dil, bir toplumdaki insanların anlaşmalarını konuşma ya da yazı ile sağlayan işaretler sistemidir.” (Ediskun, 1992: 9).

"Dil, duygu, düşünce ve dileklerimizi anlatmaya yarayan imlerin, daha çok ses imlerinin hepsine birded dil denir. Bir ulusun gerçek yurdu, onun dilidir. Dil, ulusal dileği belirten güçlü bir varlıktır. Ulusal dil yok olunca, ulusal duygu da çok geçmeden yitirilebilir." (Gencan, 1979: 1)

"Dil insanların meramlarını anlatmak için kullandıkları bir sesli işaretler sistemidir." (Banguoğlu, 1974: 9).

"Dil, düşünce, duygu ve isteklerin, bir toplumda ses ve anlam yönünden ortak olan öğeler ve kurallardan yararlanarak başkalarına aktarılmasını sağlayan çok yönlü, çok gelişmiş bir dizgedir.” (Aksan, 1979: 55)

\section{DİL VE TÜRKÇE ÖĞRETIMI}

Bireye çağdaş yaşam ve uygarlık düzeyinde vatandaş olma bilincini kazandırmanın temel öğesi eğitim ve öğretimdir. Eğitim ve öğretimin de temel öğesi “Ana Dil” olan Türkçedir.

“Ana dili, ulusu ulus yapan öğelerin en güçlüsü olduğu gerçeğidir. Öteki yönlerin tümüyle incelenmesi de bizi bu gerçeğe götürür. Toplumun bir üyesi olarak bizim toplumla bütün ilişkilerimiz ana dili aracıyla sağlanır: ama biz de ancak ana dilimizle, bir toplumun parçası oluruz.” (Aksan, 1979: 82). Ana dili; Bireylerin üstünde, devletin sınırları içinde bulunan ve milleti oluşturan etnik grupların tümünü kapsar. Ana dil toplumların ortak dilidir. Tüm ulusu ilgilendirir. Sosyal, kültürel ve ekonomik yönden birliktelik yaratır. Anlaşılabilir çözüm üretir. İşte bu çözümün yol göstericisi ana dil'dir. Coğrafî bölgelerden oluşan ülkenin değişik coğrafyalarında değişik ağız özellikleri kullanılmaktadır. Bu özellikler bir ayrıcalık oluşturmazlar. Söyleyişte farklılık gösterirler. Aralarında anlaşmazlık sorunu oluşmaz. Ülkenin dil zenginliğini ortaya koyar.

Değişik yörelerin ve etnik grupların anne dili doğal olarak yaşadıkları çevrede kullanılmaktadır. İnsanlar günlük yaşamlarını aile ortamından ve yakın çevrelerinden edindikleri dil becerileriyle ifade ederler. Bu ifade etmeler yaşayanların en doğal haklarıdır.

Ana dili, toplumun her kesiminde sarsılmaz bir birlik yaratır. Aralarında antlaşma dizgesini oluşturur. Milletleri oluşturan bütün bireyler bu birlikten paylarına düşeni alırlar. $\mathrm{Bu}$ bakımdan ana dil Milleti oluşturan ana unsurdur. Ana dil, ulus'un sarsılmaz harcıdır. Birleştiricisidir.

Okula yeni başlayan çocuklar, anne dilleri ve yaşadıkları çevrenin ağız özelliklerini ifade eden dil becerileriyle gelirler. Sürekli öğrenici olan öğretmen ise bu iki dil 
becerisinden yararlanır. Öğretmen, temel olan ana dil'e varmak için okul dilini kullanır. Ülkemizin değişik yörelerinde kullanılan anne dilleri ( Kürtçe, Zazaca, Arapça, Türkçe, Süryanice, Yezidice, Ermenice, Çerkezce, Lazca, Boşnakça, Gürcüce v.b.) ana dil potasında birleşirler. Çünkü ana dil Ulusu oluşturan unsurların başında gelir. Bu toplumsal ve ulusal olan ana dil, o Ulusun kaynaştırıcı harcıdır. Bu parçalar Ulus’ta birleşir. Çayların, derelerin nehirlerde birleştiği gibi

Eğitim ve öğretim dili olan ana dil Ulus'un da en kuvvetli birleştiricisidir. Öğretmenlerimiz, okutacakları öğrencileri bu ana dil'in birleştiriciliğinde buluşturmalıdır. Bu nedenle vereceği bütün dersleri araç olarak kullanıp, Ulus dili olan ana dile, yani Türkçe ve Türkçe Öğretimine varmalı, Türkçenin zenginliğini ve estetiğini öğrencilerine sevdirip sindirmelidir. İstanbul Türkçesini en iyi kullanan bireyler, öğretmenler olmalıdır. Öğretici kişi seslerin, sözcüklerin ve tümcelerin vurgularını, anlam ve heyecan duraklarını kurallarına uygun olarak söyleme yetisine sahip olmalıdır. Milletlerin kültür birikimini aktaran, bireyleri arasında anlaşmayı sağlayan en doğal araç kuşkusuz ana dilidir.

Dil; dinleme, konuşma, okuma ve yazma etkinliklerinin kaynağıdır. Hatta bütünüdür. Çünkü öğrencinin zihin ve ruh gelişmelerinde, Türkçe ve Türkçe Öğretiminin rolü, başka hiçbir dersle ölçülemeyecek kadar büyüktür. Yeni doğan bir çocuk, konuşmayı ve zaruri ihtiyaçlarını karşılayacak kadar bir sözcük dağarcığına sahip olur. Anne dili ve çevresinin kullandığı dilin ağız özelliğiyle okul ortamına girer. Öğretmen; Okuma-Yazma ve Türkçe derslerinde, çocuğun bu iki dil özelliğinden yararlanır. 'Okul dili'ne ya da Türkçenin estetiğine geçişi sağlayıp sınıfında dil birliği yaratması çocuğun sözcük dağarcığını, konuşabilirliğini zenginleştirecektir. Okul dili, bireyin yaşamı boyunca kullanacağı dilin temeli olacaktır. Çünkü Okul dili Resmî dildir. Bu resmî dil okunduğu gibi yazılan, yazıldığı gibi okunan dildir. En güzel örneği İstanbul Türkçesidir. Misakımilli sınırları dâhilinde Resmî dil olarak kullanılan Türk dili millî ve devlet dilidir. Devletle ilgili olandır. Devletin koşulsuz birleştiği dildir.

Dil öğretimi basamak basamak (tedrici) olduğuna göre, bu basamakların geliştirildiği yer; sınıf, rehber Öğretmendir.

Dilin tanımını, kavramını ve sosyal bir araç olduğunu irdeleyenler, ona çeşitli yönlerden yaklaşmışlardır. Bireyler arasında anlaşmayı sağlayan bu canlı araç, Milletleri birleştiren, koruyan temel harcın dil olduğunu kesinleştirmiştir. İnsanların ihtiyaç duydukları anlaşma araçları, yazılı ya da sözlü anlatımlara dayanmaktadır.

Türkçe Öğretiminde öğretmen, eğer Türk Dilinin yapısını, tümcelerini, sözcüklerini, seslemlerini ve seslerini, canlandırmada doğru ve etkin bir biçimde kavratamazsa, zorlaşan öğretimini de yapamaz. Basitten karmaşığa, kolaydan zora ya da zordan kolaya giden yöntemlerde başarı sağlayamaz. Dilin yasalarından ve söyleyiş biçimlerinden doğal olarak yararlanamaz. Türkçenin diksiyonunu, konuşma ya da yazma estetiğini en iyi kullanan bireyin öğretmen olması gerektiği kesindir.

Çağımızda hızla yenilenerek üretilen bilginin; bireyin ve toplumun geleceği, bilgiye ulaşma, bilgiyi kullanma ve üretme becerilerine bağlı bulunmaktadır. Bu becerilerin yaşam boyu kazanılması ve sürdürülmesi ezberlemeyi değil, bilgi üretimine dayalı çağdaş bir eğitimi sevdirip sindirerek bireye ve dolayısıyla topluma mal etmek gerekmektedir. Hızla gelişen bilim ve teknoloji, eğitimin her alanını etkilemekte ve özellikle eğitim yaklaşımlarında köklü değişimleri zorunlu kılmaktadır (meb, 2004: 13).

Dünyanın en çağdaş, en modern, en hoşgörülü millet tanımı Gazi Mustafa Kemal Atatürk'e ait olup, Türkiye Cumhuriyeti'nin kurucu ideolojisinde yerini almıştır. 
“Türkiye Cumhuriyeti’ni kuran Türkiye halkına Türk Milleti denir.” Diye tanımlıyor.

Kurucu ideolojimiz bunu içermektedir. Misakımilli sınırları dâhilinde; Türklük, Araplık, Kürtlük, Çerkezlik, Arnavutluk, Boşnaklık, Lazlık, Türkmenlik, Tatarlık hatta Ermenilik, Rumluk, Yezidîlik ve Süryanilik de vardır. Bunlar doğdukları yerleşim birimlerinde kendi anne dillerini konuşmaktadırlar

"Millet, aynı millî kültürde ortak olan fertlerin bütünüdür. 'Beynelmileliyet' (Milletlerarasılık), aynı medeniyete ortak olan milletlerin bütünüdür. Milletlerarasılığa 'medeniyet zümresi'de denilebilir. Fakat medeniyet zümresini, hususî bir medeniyete mensup milletlerin bütün gibi telâkki etmeyen adamlar da vardır. Bunlara göre ayrı ayrı medeniyetler yoktur. Bütün insanların mecmuu, bir tek medeniyet zümresinden ibarettir ve bu bir tek medeniyet zümresi, milletlerden değil, fertlerden kuruludur. Bu fikirde bulunan insanlara 'kozmopolit' adı verilir.” (Kaplan:1990, s105)

Millet: (a.i.c. milel) 1. Din, mezhep. 2. Bir dinde veya mezhepte bulunanların topu. 3. Sinıf, topluluk. 4. Makule, kategori (Devellioğlu, s. 775)

Millet: a. Ar. Millet 1. Çoğunlukla aynı topraklar üzerinde yaşayan, aralarında dil, tarih, duygu, ülkü, gelenek ve görenek birliği olan insan topluluğu, ulus. 2. bir yerde bulunan kimselerin bütünü, herkes: "Millet tütün paralarını alınca borcunu öder." N. Cumalı. 3. hlk. Benzer özellikleri olan topluluk: "Şu kadın milletinin kıskançlığının hiç sonu yok." A. Midhat.

"Başkalarının söyleyeceklerine engel olamazsınız." Anlamında kullanılan bir söz. “ Milletin ăgzı torba değil ki, iki gözüm dikesin. Herkes dilediği hikmeti savurmakta muhtardır. ” N. Hikmet (T.D. K. Türkçe sözlük, s.1683.)

Temelinde Ulus Devlet harcı bulunan milletlerin; hiçbir etnik, mezhepsel, dinsel, sosyal, kültürel nedenlerle ayrıştırılması mümkün değildir. Bunun anlamı; Misakımilli sınırları dâhilinde Türklük, Araplık, Kürtlük, Çerkezlik, Arnavutluk, Boşnaklık, Lazlık, Türkmenlik, Zazalık, Tatarlık hatta Ermenilik, Rumluk ve Süryanilik, Yezidîlik de vardır. Bütün bu etnik grupların anlaşabildiği ortak dil ANA DİL'dir. BU DA TÜRKÇEDİR.

\section{DÍL AÍLELERİ VE TÜRKÇE}

"Dünya diller kümesi içerisinde, dilcilerce yapılan jenealojik tasnif üzerine, Türk Dili ve halklarının şiveleri, Altay dilleri grubuna dâhil edilmektedir. (Caferoğlu, 1970: 10)

"Bununla beraber, uzun araştırmalar sonucunda bu ad altında birleştirilen Türk, Moğol ve Mançu - Tunguz dilleri, ilk önce Fin - Ugor dilleri ile bir aileden sayılmasına rağmen, sonraları daha geniş bir diller ailesi grubu olan Ural - Altay manzumesi içerisinde tetkike layık görülmüştür.

\section{Ural Altay Dilleri Ailesi}

"Bu dil zümresine giren diller şunlardır: (Beş dil zümresi)

I. Fin - Ugor grubu: İki büyük dil dalına ayrılır.

a. Ugor dili. Buraya 1) Ostyak, 2) Vogul, 3) Macar dilleri girer.

b. Fin dalı. Bu dala 1) Asıl Fin = Suomi dili, 2) Est, 3) Liv [Kurland'ın Şimalinde], 4) Karel [ ki budört dil Baltık dil grubunu teşkil etmektedir], 5) Lap, 6) Votyak, 7) Züryen, 8) Çeremis, 9) Mordvin [Perm ve Volga grubunu vücuda getirir], dilleri dâhildir.

II. Samoyed grubu. Şimal Buz denizinin Avrupa ve Asya sahillerinde yaşayan bu kavmin dili morfoloji ve söz benzerliği yönünden Fin - Ugor dil grubuna yaklaşmaktadır. 
III. Türk Dili grubu: 1) Yakut ve 2) Çuvaş lehçeleri, 3) Cenubî Sibirya Türkleri: a) Karagas, b) Kamasin, 4) Abakan Türkleri: a) Kızıl, b) Kaç, c) Koybal, d) Sagay, e) Beltir, 5) Çulım Türkleri: 6) Şimalî Altay Türkleri, a) Kumandı yahut Kumandı kişi, b) Lebed, c) Tuba yahut Kara Orman Türkleri, ç) Şor, 7) Asıl Altay Türkleri: a) Altaylilar, b) Dvoyedanlar, c) Teleüt, d) Altay Dağ Kalmukları, 8) Moğolistan garbındaki Türkler: a) Uryanhay, b) Baraba, 9) İrtiş ve Tobol Türkleri, a) Tara Türkleri, b) Tobol Türkleri, c) Tümen ve Tobol'sk Türkleri, 10) Kara Kırgız, 11) Kazak Kırgız, 12) Şarkî Türkistan Türkleri: a) Tarançı, b) Kaşgarlık, c) Hâmi Türkleri, 13) Garbî Türkistan Türkleri: a) Özbek, b) Kurama, c) Karakalpak, ç) Türkmen, 14) Volga Türkleri: a) Başkırt, b) Kazan Türkleri, c) Mişer, ç) Tepter 15) Şimalî Kafkasya Türkleri: a) Nogay, b) Kundur, c) Kumuk, ç) Karaçay, d) Balkar, 16) Garp Türkleri: a) Türkiye Türkleri, b) Azerî'ler, 17) Kırım Türkleri: a) Kırım Karaimleri, 18) Litvanya ve Lehistan Karaimleri, 19) Gagauz, 20) Balkan Türkleri, 21) Suriye ve Irak Türkleri.

IV. Moğol grubu: 1) Buryat, 2) Kalmuk, 3) Oyrat, 4) Halha vesaire. Buraya, tarihleri ve gelişmeleri ile ayrı bir Moğol dili grubu teşkil eden; 1) Moğol [Afganistan'da], Dagur [Mançurya'da] ve Mongor [Tibet-Çin]ler girerler.

\section{Tunguz dalı: 1) Mançu, 2) Lamut, 3) Tunguz Şiveleri girer.}

Türk dili grubuna giren Türkçeler, her ne kadar Avrupa Türkologları tarafindan âdeta müstakil birer dil olarak telâkki edilmekte ise de, gerçekte birer şiveden başka bir şey değildirler. Yalnız, geniş ve zengin morfolojik ve sözlük hususları ile Yakutça ve Çuvaşça, umum Türkçeye karşı bariz ayrılıklar gösterdiklerinden, biz de burada kendilerine "lehçe" adı verilmesi lüzumunu hissettik. Oysa ki diğerleri, hiçbir zaman müstakil bir sarfa veya ayrı telâkki edilebilir bir kelime servetine malik olmayıp Türkçemizden anlaşılmayacak kadar ayrılmamışlardır." (Caferoğlu, 1970: 20-21)

Böylece Orta Asya'da, Bulgaristan'da ve Irak'ta konuşulmakta olan Türk dilleri, birer Türkiye Türkçesi şiveleridir. Basit bir tanımla bir dilin anlamı ve yazılışı aynı, söylenişte farklılık gösteren şubesine "ağız"; anlamı aynı, yazılış ve söylenişte farklılık gösteren şubesine "şive"; bilinmeyen bir zamanda o dilden tamamen ayrılmış, anlamı, yazılışı ve söylenişi farklı olan şubesine de "lehçe" denir.

\section{TÜRKÇE ÖĞRETIMINDE ÖĞRENME ALANLARI:}

Türkçe Öğretimi; dinleme, konuşma, okuma, yazma, görsel okuma ve görsel sunu'dan oluşan beş öğrenme alanı üzerine yapılandırılmıştır. Türkçe öğretimi ve dil, öğrencilere bilgiden çok temel beceriler kazandırılması ilkesine dayanır.

\section{a. Dinleme;}

Dinleme: seslerin ve konuşmaların anlamlandırıldığı karmaşık bir süreçtir. $\mathrm{Bu}$ süreç; işitme, dikkat yoğunlaştırma ve anlamlandırma aşamalarından oluşmaktadır.

Dinleme: (is.) Dinlemek işi,

Dinlemek: 1. İşitmek için kulak vermek, (şarkı dinlemek) 2. Birinin sözünü, öğüdünü kabul edip gereğince davranmak: (beni dinlersen, bu işten vazgeç.) 3. Uymak, baş eğmek, itaat etmek, 4. Kulakla veya dinleme aletiyle hastayı muayene etmek (T. S, 1988: 379),

İşitme dinleme sürecinin ilk aşamasıdır. Ancak dinleme, işitmeden farklı olarak dikkat yoğunlaştırma ve anlamlandırma gibi zihinsel işlemleri de gerektirir. Bu nedenle dinleme, amaçlı bir zihinsel etkinliktir. Dinleme süreci ses ile sözel uyarıcıların işitilmesiyle başlamaktadır. İkinci aşamada uyarıcılara dikkat yoğunlaştırılarak ilgi duyulan ve gerekli olanlar seçilmektedir. 
Seçilen bilgi ve düşünceler anlama, sıralama, sınıflama, ilişki kurma, düzenleme ve değerlendirme gibi çeşitli zihinsel işlemlerden geçirilmektedir. Dinleme sürecinde dikkat yoğunlaştırma önemli bir aşama olmakta ve bütün süreci etkilemektedir. Özellikle işitilenlerin seçilmesi, işlenmesi ve anlamlandırılmasında belirleyici olmaktadır. Öğrencinin dinleme amacını, yöntemini belirlemesi; dinleme sürecini denetim altına almasını ve dikkatini yoğunlaştırmasını sağlamaktadır.

Çocuklar dil edinme sürecine dinleme ile başlarlar. Dinleme, konuşma, okuma ve yazma gibi diğer alanlara da temel oluşturur. Çocuklar, hem öğrenmek hem de zihinsel yapılarını geliştirmek amacıyla dinleme becerilerini kullanırlar. Dinleme yoluyla öğrencilerin iletişim kurması, öğrenmesi ve zihinsel yapısını geliştirmesi kolay olmaktadır. Dinleyerek öğrenen öğrenciler, bu becerilerini bir öğrenme aracı olarak hayatları boyunca kullanırlar. Bu nedenle öğrencilerin dinleme becerileri erken yaşlarda geliştirilmelidir.

Dinleme alanında kazandırılacak becerilerin başında zihinsel hazırlık gelmektedir. Öğrencinin dinleme amacını belirlemesi, buna uygun yöntem seçmesi ve dinlemeye dikkatini yoğunlaştırması gerekmektedir. $\mathrm{Bu}$ çalışmalar öğrencinin hem dinlediklerini anlamasını, yorumlamasını, zihinde yapılandırmasını hem de zihinsel becerilerini geliştirmesini kolaylaştırıcı olmaktadır.

$\mathrm{Bu}$ amaçla öğrencilere dinlediklerini zihninde canlandırma, sınıflama, sorgulama, ilişki kurma, çıkarımlar yapma, sonucu tahmin etme, özetleme, değerlendirme ve arkadaşlarıyla paylaşma gibi çalışmalar yaptırılmalıdır (meb, 2004: 17 -18).

\section{b. Konuşma:}

Konuşma, dil aracılığıyla gözlemleri, düşünceleri, duyguları ve bilgileri anlatma işlemidir. Konuşma, evde, okulda ve sosyal ilişkilerde kullanılan temel bir beceridir. $\mathrm{Bu}$ beceriyle duygu ve düşünceler aktarılmakta, bilgi ve deneyimler paylaşılmaktadır. Konuşma zihinde başlayan ve düşüncelerin sözle ifade edilmesiyle tamamlanan bir süreçtir. $\mathrm{Bu}$ sürece zihinsel işlemlerle başlanmakta ve öncelikle zihinde yapılandırılmış bilgiler gözden geçirilmektedir.

Konuşmanın amacı, yöntemi, konusu ve sınırları belirlenmektedir. Ardından aktarılacak bilgiler seçilmektedir. Seçilen bilgiler çeşitli zihinsel işlemlerden geçirilmektedir. Bu işlemler sıralama, sınıflama, ilişki kurma, eleştirme, tahmin etme, analiz - sentez yapma ve değerlendirme gibi zihinsel işlemler olmaktadır. Bu işlemler sonucunda düzenlenen bilgiler cümlelere, dökülerek aktarılmaktadır.

Konuşma, dinleme ile doğrudan bağlantılıdır. Çocuklar önce çevrelerindeki kişilerin diliyle konuşmaya başlarlar. Önce anne-baba ve yakın aile bireylerinden duyup taklit ederek anne dillerini öğrenirler, sonra çevre dili, daha sonrada sınıfta "okul dilini" öğrenirler. Öğretmen Okul Dilinde Türkçenin diksiyonuna en uygun ağız özelliğini içeren İstanbul Türkçesini kullanmalıdır. Unutulmamalıdır ki, taklit edilen birinci unsur ÖĞRETMENDİR.

"Konuşma öğrencilerin etkileşimleri, işbirliği yapmaları, tartışmaları, ortak karar vermeleri ve sorun çözmeleri açısından da önemli bir alandır. Öğretmen sınıfta konuşma ağırlıklı öğrenme etkinliklerine daha fazla yer vermelidir.” (meb, 2004: 20)

Konuşma alanında kazandırılacak temel becerilerin başında Türkçenin doğru ve akıcı kullanımı gelmektedir. Bunun temelinde de dinleme, sözcükleri doğru söyleme yer almaktadir. 
Doğru, düzgün, etkili konuşabilmek için çok okumak gerekir. Çok okumak, sözcük dağarcığına çok sözcük katmak demektir. Konuşmanın, düşünmenin, iletişim kurmanın tek dayanağı sözcüklerdir.

Sevgi limanı olan öğretmen, öğrencilerini konuşturmalıdır. Çocuklar içlerinden geldiği gibi konuşmalıdırlar. Sözleri kesilmemeli, saygıyla dinlenmeliler ki, konuşma istekleri artsin.

\section{c. Okuma:}

Okuma; gözlerin gördüğünü resmetmesinden, ses organlarının da resmedilenleri çeşitli hareketlerle canlandırmasından meydana gelen ve bütün bu eylemlerle birlikte zihnin algılaması ile oluşan karmaşık bir hareketler bütünüdür. Okuma; zihnin gelişimine en büyük katkıyı sağlayan bir öğrenme alanıdır.

Tanımı: gözlerin ve ses organlarının çeşitli hareketlerinden ve zihnin anlamı kavrama gayretinden meydana gelen, oldukça karmaşık bir etkinliktir. Çelik:2011, s,60)

“Okuma demek kelimeleri ya da cümleleri görmek demek değildir; okuyabilmek, özellikle anlayarak okuyabilmek için görmenin ötesinde bir takım zihinsel etkinlikler gereklidir. Okuma bir algısal etkinliktir, bir düşünce sürecidir.”(Dökmen 1994:15)

\section{d. Yazma:}

Öğrencilere kazandırılması gereken beş beceriden biridir. Duyguların, düşüncelerin, isteklerin, tasarıların yazılı olarak ifade edilmesidir. Yazma becerisi uygulamalarla elde edilir. El alışkanlıkları, parmak kaslarının geliştirilmesi bireyi bu beceriye sahip kılar.

Bireyin önbilgilerini kullanma, görsellerden yararlanma, düşüncelerini sözcüklerle ifade etme, düşünmeye yönlendirme, sebep - sonuç ilişkisi kurma, değerlendirme, özetleme gibi zihinsel becerileri geliştirici çalışmalara yer vermek gerekir. Bilgi edinmek için yazma, ikna edici, betimleyici ve serbest yazma gibi çeşitli yöntem ve teknikler de kullanılmalıdır.

\section{e. Görsel Okuma ve Görsel Sunu:}

Görsel Okuma ve görsel sunu Türkçe Programı'nda ilk kez ele alınmıştır. Bu öğrenme alanı yazılı metinlerin dışında kalan şekil, resim, sembol, grafik tablo, beden dili, doğa ve sosyal olaylar gibi görselleri okuma, anlama ve yorumlamayı kapsamaktadır.

\section{SONUÇ}

Bütün bu yetiler gerektiren etkinlikler kaynağını ana dilden alırlar. Anne dili ve çevre dili, okulda ANA DİL'de birleşirler. Çayların ve derelerin nehirlerde birleştiği gibi.

Tedrici öğrenilen anne ve çevre dilleri özelliklerinin kaynağı, Türkiye Cumhuriyeti Devletinin Ulus dili olan dil, ana dil'dir. Bu ana dil , halis Türkçe'dir.

\section{KAYNAKLAR}

Aksan, D. (1979) Her Yönüyle Dil Ana Çizgileriyle Dilbilim c. I Ankara: Türk Dil Kurumu Yayınları - 439.

Aksan, Prof, Dr. D, (1982), Her Yönüyle Dil, T. D. K. Yayınları, Cilt 1. II. III. Ankara Üniversitesi Basımevi, Ankara.

Aksan, Prof. Dr. D, (1978), Anlambilimi ve Türk Anlambilimi (Ana Çizgileriyle) 2. Basım, Erol Ofset Matbaacılık, Ankara.

Banguoğlu, Tahsin. (1974) Türkçenin Grameri, Baha Matbaası, İstanbul. 
Caferoğlu, A. (1970), Türk Dili Tarihi, c. II İstanbul Üniversitesi Edebiyat Fakültesi Yayınları No: 778, (Genişletilmiş 2. baskı): İstanbul.

Çelik C. Ergun. (2011), Türkçe Öğretimi, s, 60 Kriter Yayınları, İstanbul.

Demirel, Özcan (1999), Türkçe Öğretimi, Pegam A Yayıncılık. Ankara.

Derleme Sözlüğü, (1993), Atatürk Kültür, Dil ve Tarih Yüksek Kurumu Türk Dil Kurumu Yayınları, 2, Baskı Ankara Üniversitesi Basımevi, Ankara. Ankara.

Devellioğlu, Ferit (1984) Osmanlıca-Türkçe Ansiklopedik Lûgat Aydın Kitapevi

Dökmen, Üstün (1994), Okuma Becerisi, İlgisi ve Alışkanlığı Üzerine Psiko - Sosyal Bir Araştırma, Milli Eğitim Bakanlığı Yayınları: 2531, İstanbul.

Ergin, Prof. Dr. M. Türk Dil Bilgisi: (1958), s.62 İ.Ü. Edebiyat Fakültesi Yayını, İstanbul.

Ergin, Prof. Dr. M. Türk Dil Bilgisi: (1977), Eğitim Enstitüleri- Yüksekokullar ve Temel Bilimler Fakülteleri İçin: Minnetoğlu Yayınları, İstanbul. İstanbul.

Ergin, Prof. Dr. M. Üniversiteler İçin TÜRK DİLİ, (1986), Boğaziçi Yayınları,

Ediskun, H. (1992), Türk Dilbilgisi: Sesbilgisi-Biçimbilgisi- Cümle bilgisi: Remzi Kitapevi İstanbul.

Gencan, T. N. (1979) Dilbilgisi: Gözden Geçirilmiş 4. Baskı: Ankara Üniversitesi Basımevi, Türk Dil Kurumu Yayınları - 418, Ankara.

Kaplan, Prof. Dr. Mehmet, Kültür ve Dil, Ekim 1982 Dergâh Yayınları, İstanbul.

Kaplan, Prof. Dr. Mehmet, Türkçülüğün Esasları, 1990, s123, MEB Yayınları, İstanbul

Koç, N.. (1990), Yeni Dilbilgisi: İnkılâp Kitapevi, İstanbul

(T.D. K. Türkçe sözlük, s.1683.)

Önder Mehmet, Atatürk'ün Yurt Gezileri, Türkiye İş Bankası Kültür yayınları, Ankara, 1998, s.8)

Temel, Çevik Ersin (1989) 14.05.1989 Tarihli Konferans Metni İlköğretim Öğretmenleri için, [Şehit İlköğretim Müfettişi RAHMETLE anıyorum. ] Siirt

İlköğretim Türkçe Öğretim Programı ve Kılavuzu (1-5. Sınıflar) (2005) T. C. Milli Eğitim Bakanlığı Talim ve Terbiye Kurulu Başkanlığı, Devlet Kitapları Müdürlüğü Basım Evi, Ankara.

T. C. Milli eğitim Bakanlığı İlköğretim Türkçe Öğretim Programı, Ünitelendirilmiş Planlar (1 -8. Sinıflar), 1 ve 5. sinıfların birinci temaları)

T.D.K.Türkçe Sözlük, (1988), Atatürk Kültür, Dil ve Tarih Yüksek Kurumu Türk Dil Kurumu, Yeni Baskı, Ankara.

Tarama Sözlüğü, (1996), Atatürk Kültür, Dil ve Tarih Yüksek Kurumu Türk Dil Kurumu Yayınları, 2. Baskı VIII Cilt, Ankara Üniversitesi Basımevi, Ankara. 